\title{
ZÁKLADNÍ HODNOTY V RÁMCI PROCESU NATURALIZACE CIZINCŮ V ČESKÉ REPUBLICE ${ }^{1}$
}

\author{
PAVEL KANDALEC
}

\begin{abstract}
Basic Values within the Process of Naturalization of Foreigners in the Czech Republic The article ponders the question whether certain basic values are reflected in the process of naturalisation of foreigners. Although we may think that these values are the ones forming the basis of the standards of our supreme constitutional level, a practical survey carried out shows that there are other, somewhat different decisive criteria. It is also quite interesting to see the conclusion of an analysis of the applicants' standpoints showing that the gap between their expectations and reality is much wider.
\end{abstract}

Keywords: citizenship; naturalisation; basic values; integration

Klíčová slova: státní občanství; naturalizace; základní hodnoty; integrace

DOI: $10.14712 / 23366478.2018 .3$

Naturalizace, tj. získání státního občanství na žádost cizince, je proces, o kterém téměř každý slyšel, ale zdaleka ne každý jej na vlastní kůži prožil. Je to také proces, při kterém si lidé obvykle vybaví určité hodnoty a očekávají, že tyto hodnoty v něm budou hrát svou roli. Logickým problémem pak je, že lidé jsou různí a jejich hodnoty jsou taktéž rozmanité. Škála představ o tom, co je při naturalizaci skutečně důležité, je pak velmi široká. Není proto ambicí tohoto prŕíspěvku projektovat do něj osobní hodnotové zaměření autora, nebot' by se tím debata rozšířila jen o jediný další názor. Tento příspěvek má naopak ambici být příspěvkem nezaujatého pozorovatele shrnujícího stav, který tu existuje a který dosud nebyl v odborné literatuře zpracován.

Zjištění uvedená níže v tomto příspěvku jsou založena na analýze více než 1600 rozhodnutí o zamítnutí žádostí o státní občanství České republiky vydaných v první instanci Ministerstvem vnitra, a v př́ípadě podání rozkladu i v druhé instanci ministrem vnitra, v období let 2013-2016. Celkově bylo analyzováno 1123 zamítnutých př́padů, z nichž u 623 byl rozhodným předpisem zákon č. 40/1993 Sb., o nabývání a pozbývání státního občanství České republiky, (dále jen ,ZNPSO“)² a u 500 případů

1 Tento příspěvek vznikl v rámci výzkumu Naturalizace v České republice (GA15-07626S), přičemž vychází z analýzy více než 1600 rozhodnutí o zamítnutí žádostí o udělení státního občanství České republiky vydaných Ministerstvem vnitra, příp. ministrem vnitra v letech 2013-2016. Analyzovaná rozhodnutí, která představují téměř 100 \% všech vydaných negativních rozhodnutí, jsou citována podle pracovních čísel (,prac. č.“) a jsou všechna dostupná na: naturalizace.law.muni.cz.

2 Tento zákon byl účinný v letech 1993-2013. Vzhledem k tomu, že žádosti o státní občanství České republiky jsou rozhodovány podle zákona účinného ke dni jejich podání, je tento zákon v některých případech i nadále aplikován, přičemž v letech 2014 a 2015 jeho aplikace převažovala i přesto, že v té době již nebyl účinný. 
se již postupovalo podle zákona č. 186/2013 Sb., o státním občanství České republiky, (dále jen „ZSO“). ${ }^{3}$

Pojednávanou problematiku lze uchopit ze tř́ úhlů pohledu: (1) z pohledu existující právní úpravy, (2) z pohledu žadatelů samotných a (3) z pohledu praxe. V ideálně fungujícím modelu by se měly všechny tyto tři pohledy překrývat. Čtenář však jistě již tuší, že tomu tak ve skutečnosti není - aktéŕi naturalizačního procesu mají o jeho průběhu rozdílnou představu. Pojd’me si tedy ukázat, na jakých hodnotách je naturalizace v České republice založena. Co o této otázce lze vyčíst ze zákona? Jaké hodnoty považují samotní žadatelé za relevantní? A jaká je nakonec realita - tj. jaké hodnoty hrají při rozhodování naturalizujícího orgánu (Ministerstva vnitra) skutečně roli.

\section{PRÁVNÍ ÚPRAVA}

Podmínky pro udělení státního občanství České republiky jsou s účinností od 1. 1. 2013 stanoveny již výše zmíněným zákonem č. 186/2013 Sb., o státním občanství České republiky. O základních hodnotách se v něm samotném však mnoho nedočteme. Jak o tom ještě bude pojednáno níže, je nakonec většina podmínek pro naturalizaci v České republice nastavena negativně - tj. jako možné překážky, nikoliv jako předpoklady. Marně bychom tedy hledali výslovné ustanovení obdobné např. § 10 odst. 1 německého StAG, ${ }^{4}$ dle něhož je podmínka naturalizace v SRN ztotožnění se s ,,freiheitlichen demokratischen Grundordnung des Grundgesetzes für die BRD “- tedy se svobodným demokratickým uspořádáním dle německého Základního zákona.

Odkaz na ústavní normy bychom v procesu naturalizace v České republice hledali marně. S požadavkem na dodržování „Ústavy“ se setkáváme až ve státoobčanském slibu zakotveném v $§ 27$ odst. 2 ZSO, který zní: „,Slibuji na svou čest věrnost České republice. Slibuji, že budu dodržovat jeji Ústavu a ostatni zákony České republiky. “

Tento slib je však jen završením celého správního řízení o udělení státního občanství České republiky. Jeho složení je poslední podmínkou, kterou žadatel musí splnit, nebot' státní občanství České republiky se, odhlédneme-li od některých výjimek, nabývá až dnem složení státoobčanského slibu (§ 27 odst. 1 ZSO). Podstatné však je, že vážnost tohoto slibu už není a ani nemůže být nikterak přezkoumávána a jeho následné nedodržení (tj. následné nedodržování Ústavy a zákonů České republiky ze strany naturalizovaného cizince) již na získání státního občanství České republiky nic nemění. Lapidárně řečeno, již jednou udělené státní občanství nemůže být dle české právní úpravy za trest odňato. ${ }^{5}$ Jediným důvodem pro zrušení již jednou uděleného státního občanství České republiky je obnova rrízení podle $\S 39$ ZSO - ta se však týká jen podvodného jednání

3 Tento zákon je účinný od 1. 1. 2014. Vzhledem k tomu, že žádosti o státní občanství České republiky jsou rozhodovány podle zákona účinného ke dni jejich podání, docházelo k nástupu aplikace tohoto zákona velmi pozvolna, kdy paralelně byla vydávána i rozhodnutí podle předchozí právní úpravy. Teprve až přibližně od konce roku 2015 je již většina rozhodnutí vydávána podle tohoto nového předpisu.

4 StAG - Staatsangehörigkeitsgesezt - zákon o státní prŕíslušnosti Spolkové republiky Německo.

5 Tento zákaz je v důsledku neblahých zkušeností s odnímáním československého státního občanství před rokem 1989 dnes již výslovně zakotven i v čl. 12 odst. 2 Ústavy České republiky: ,, Nikdo nemũže být proti své vůli zbaven státního občanství. “ 
žadatele $\mathrm{v}$ průběhu správního řízení o udělení státního občanství, nikoliv jakéhokoliv protiprávního jednání žadatele po jeho skončení.

Ačkoliv je státoobčanský slib zpravidla nutnou podmínkou pro naturalizaci v České republice a je tedy formálně vzato součástí celého naturalizačního procesu, z materiálního hlediska je o udělení státního občanství již rozhodnuto nejpozději v okamžiku, kdy je žadatel ke složení tohoto slibu Ministerstvem vnitra vyzván. Jaké hodnoty tedy lze vyčíst z právní úpravy upravující proces naturalizace do právě zmíněného rozhodného okamžiku?

Prostor pro zdůraznění základních hodnot poskytuje zkouška z reálií (tj. ze základní znalosti ústavního systému České republiky a základní orientace v kulturně-společenských, zeměpisných a historických reáliích České republiky), která je dle § 14 odst. 5 ZSO jedním z předpokladů pro udělení státního občanství České republiky. Ta je však založena převážně na faktických otázkách - např. jaká je rozloha České republiky, jaké telefonní číslo má zdravotnická záchranná služba, který den si Češi obvykle dávají vánoční dárky či který pivovar vyrábí pivo značky Pilsner Urquell. ${ }^{6} \mathrm{~V}$ tomto ohledu se liší např. od podobné zkoušky (Einbürgerungsstest) vykonávané v SRN, ve které je řada otázek zaměřena hodnotově - např zda mohou lidé v SRN vyjádřit nějakou kritiku vůči vládě, co se rozumí pojmem sociální stát, zda lze mít vícero manželů/manželek zároveň či zda je možné se v životě vícekrát oženit/vdát. ${ }^{7}$

Nastavení otázek v rámci této zkoušky z reálií může být zřejmě tou nejrychleji realizovatelnou cestou, jak promítnout do procesu udělování státního občanství České republiky základní hodnoty, na nichž je Česká republika založena. Jiná otázka však je, zda má tato zkouška jako taková vůbec nějaký praktický smysl. Úspěšnost uchazečů při ní je asi $99 \%{ }^{8} \mathrm{~V}$ žádném ze zkoumaných prípadů nebyla žádost zamítnuta pouze $\mathrm{z}$ důvodu nesplnění podmínky znalosti reálií (kód ${ }^{9} \mathrm{U}$ ). Pokud už se tento důvod zamítnutí vyskytl (5×), tak vždy jen v situaci, kdy se žadatel této zkoušky odmítl vůbec zúčastnit. ${ }^{10}$

Současná právní úprava státního občanství České republiky (ZSO), podobně jako úprava předchozí účinná v letech 1993-2013 (ZNPSO), definuje podmínky pro naturalizaci především negativně - tj. stanoví skutečnosti, které, pokud nastanou, zakládají důvod pro nevyhovění žádosti. Tyto negativní podmínky mají pak v praxi různou frekvenci výskytu a bude o nich pojednáno níže.

Pokud jde o již předem stanovené hodnoty, které by měly být předpokladem pro získání státního občanství České republiky, pak jsou nastíněny v $\S 13$ odst. 1 ZSO, podle nějž: , Státni občanství České republiky lze udělit, pokud je žadatel integrován do společnosti v České republice, zejména pokud jde o integraci z hlediska rodinného, pracovního, nebo sociálního, a splňuje ostatní podmínky stanovené $v \S 14$."

\footnotetext{
6 http://obcanstvi.cestina-pro-cizince.cz/?p=databanka-testovych-uloh-z-ceskych-realii\&hl=cs_CZ

7 SCHRÖTTER, H. J.: Mein Einbürgerungstest.München, 2016, s. 218.

8 Údaj získaný z rozhodnutí Ministerstva vnitra prac. č. 0815.

9 Jednotlivým důvodům vedoucím $\mathrm{k}$ zamítnutí žádosti byly v rámci tohoto výzkumu přiděleny kódy - blíže viz naturalizace.law.muni.cz.

10 Rozhodnutí Ministerstva vnitra prac. č. 0653, prac. č. 0665, prac. č. 0763, prac. č. 0770 a prac. č. 0815.
} 


\section{POHLED ŽADATELŮ}

Adresáti citovaného ustanovení tedy cítí, že by měli naturalizační orgán přesvědčit, že jsou do společnosti v České republice ,,integrováni“. Zde však nastává problém dosahující někdy až anekdotických rozměrů. Nikde totiž není a ani nemůže být stanoveno, co se touto integrací vlastně myslí. Podívejme se nyní, jaká hlediska považují za relevantní samotní žadatelé. Při podávání žádosti o státní občanství České republiky ostatně žadatelé předkládají i svůj životopis, v němž mohou svoji integraci a př́ípadně i př́nos pro Českou republiku představit.

Pro korektnost je třeba nicméně předeslat, že níže uvedené př́íklady se týkají toliko situací žadatelů, jejichž žádosti nebylo Ministerstvem vnitra vyhověno. Argumentace žadatelů je pak čerpána především z jejich opravného prostředku (rozkladu) proti tomuto rozhodnutí. Celá paleta dalších argumentů v př́padech, kdy žádosti naopak vyhověno bylo, zůstala zcela mimo dosah tohoto výzkumu. ${ }^{11}$

\section{EKONOMICKÝ PŘÍNOS}

Nezanedbatelnou skupinu žadatelů tvoří ti, kteří apelují na svůj významný ekonomický př́nos pro Českou republiku, byt zákonná úprava v České republice takové hledisko výslovně vůbec nestanoví. Intuitivně však mezi žadateli panuje určitý mýtus o tom, že bohatší žadatelé by zároveň měli mít na získání státního občanství vyšší šance. Tento mýtus je navíc posilován některými zahraničními právními úpravami - asi nejznámějš́ je tu př́ípad Malty, která své státní občanství doslova „prodává“. 12

Př́íladem tu může být žadatel původem z Ruska, prac. č. 0507, který doložil kopii certifikátu o přijetí do encyklopedie WHO IS WHO?, dále fotokopii ceny za rok 2005 udělenou mu Sdružením léčebních lázní v Karlových Varech a dále též ocenění Hoteliér roku 2005. Žadatel za uplynulých 19 let proinvestoval prostřednictvím jím řízených společností přes 40 milionů EUR, zaměstnal několik stovek lidí, dal práci několika desítkám stavebních firem a přivedl do České republiky řadu zahraničních investorů a návštěvníků.

Jiný žadatel, původem taktéž z Ruska, prac. č. 0537, pak poukázal na to, že jeho společnost získala stavební povolení na Praze 1, kde bude rekonstruovat budovu na hotel a byty a tento rozsáhlý projekt tedy svědčí o jeho začlenění do České republiky a prínosu pro český stát.

11 Stejně tak zůstává opomenuta výjimečná možnost získání státního občanství z důvodu významného př́ínosu pro Českou republiku dle $§ 16$ ZSO, kdy může být státní občanství uděleno za zjednodušených podmínek žadateli, u něhož by toto udělení bylo významným př́nosem pro Českou republiku z hlediska vědeckého, vzdělávacího, kulturního, sportovního, humanitárního, plnění mezinárodních závazků České republiky nebo je v jiném státním zájmu. To se však týká ročně jen asi desítky osob, které tak tvoří méně než 1 procento z celkového počtu naturalizovaných osob.

12 Úprava státního občanství Malty se stala předmětem odborné kritiky, když bylo mimo jiné poukazováno na to, že to, co Malta fakticky nabízí, není primárně státní občanství tohoto malého státu, ale s tamním občanstvím spjaté občanství Evropské unie - blíže srov. SHACHAR, A. - BAUBÖCK, R.: Should Citizenship be for Sale? EUI Working Paper, 2014, č. 1. Podrobněji k unijnímu rozměru problematiky viz též ŘIĆCKA, R. - SEHNÁLEK, D.: Neřešené problémy úpravy unijního občanství aneb Malta zlobí. Časopis pro právní védu a praxi, 2015, č. 4, s. 331-341. 


\section{KULTURNÍ A HUMANITÁRNÍ PŘíNOS}

Další skupinu žadatelů tvoří ti, kteří poukazují na svůj př́ínos při zapojení do nejrůznějších kulturních a humanitárních aktivit v České republice.

Žadatel původem z Vietnamu v př́padě prac. č. 0088r poukázal v rozkladu na naplnění svého úzkého vztahu k České republice, který spatřuje zejména v oblasti společenské, kulturní a humanitární, kdy působí jako spoluzakladatel dětského divadla a režíroval dětské divadelní hry bez nároku na honoráŕ. Dále působí jako místopředseda Svazu Vietnamců v ČR, jehož předmětem činnosti je integrace vietnamské komunity do české společnosti. V této funkci podpořil rozhodnutí tohoto svazu na vyčlenění prríspěvku na humanitární pomoc českým městům postiženým povodněmi v letech 2002, 2012 a 2013, naposledy přitom byla vyčleněna částka 320 tis. Kč na pomoc hlavnímu městu Praze. Dále je šéfredaktorem týdeníků Tuan Tin Moi (Týden nových zpráv) a The Gioi Tre (Svět mladých). Prostřednictvím těchto týdeníků zprostředkovává čtenářo̊m informace o dění ve Vietnamu a v České republice, včetně příspěvků z oblasti stěžejních českých právních předpisů, zejména $\mathrm{v}$ oblasti pobytového režimu a azylového práva. Týdeník bezplatně zpř́stupňuje i osobám vietnamského původu vazebně stíhaným nebo ve výkonu trestu odnětí svobody.

$\mathrm{V}$ př́ípadě prac. č. 0456r žadatel původem z Ukrajiny k rozkladu přiložil poděkování Dětského domova Vysoká Pec za sponzorský dar a poděkování Ludvíka Hesse za velkorysý dar na zř́zení babyboxu v Nemocnici Znojmo, z čehož tedy vyplývá, že žadateli není lhostejný osud společenství občanů České republiky.

Lhostejnost ke společnosti nelze vyčitat ani žadateli původem z Ruska, prac. č. 0361, který předložil vyznamenání - Řád sv. Cyrila a Metoděje od pravoslavného arcibiskupa pražského a českých zemí, potvrzení pro dárce krve, členský průkaz folklorního sdružení pro folklorní soubor Kozáci Vltavy, děkovný dopis archimandrity Izaiáše z Monastýru sv. Prokopa Sázavského za brigádní pomoc v budově monastýrů a další děkovné dopisy vztahující se k činnosti Kozáctva v České republice.

Všechny právě zmíněné důvody uváděné žadateli mají z hlediska společenského nesporně svoji relevanci. Že státní občanství České republiky nebylo v žádném z výše citovaných př́padů uděleno, má své jiné příčiny, o kterých bude pojednáno níže.

\section{PSEUDOPŘÍNOSY}

Ze strany žadatelů se lze setkat i s dalšími argumenty, pro něž by jim dle názoru těchto žadatelů mělo být státní občanství České republiky uděleno. Některé z těchto uváděných důvodů jsou vskutku kuriózní a ukazují, jak hluboká je někdy propast mezi představou žadatelů samotných a realitou.

Žadatel původem z Alžírska, prac. č. 0131, uvedl na podporu své žádosti o státní občanství České republiky, že již po dvou týdnech pobytu v Praze byl natolik okouzlen Prahou, že už věděl, že se nechce vrátit domů, a proto požádal o udělení mezinárodní ochrany.

Rovněž žadatel, původem z Pobřeží slonoviny, prac. č. 0439, argumentoval svým vztahem k České republice. Po deseti letech v České republice se cítí jako Čech a mluví 
o této zemi jako o svém domovu. Má rád českou kulturu, české jídlo a pivo. Se svou př́telkyní a matkou svého dítěte se dívá na televizi a občas také společně píší diktáty.

Svoji představu o ryze českých hodnotách představil i žadatel původem z Ruska, prac. č. 0355, který argumentoval tím, že daroval občanskému sdružení Hockey Club Slavia Praha, o.s. finanční dar ve výši 75 000,- Kč a dále doložil kladné a vlastnoručně podepsané vyjádření ke své osobě od hokejového trenéra a ortopeda.

Podobně žadatel původem z Kosova, prac. č. 0008, uvedl, že je aktivní amatérský fotbalista a je spolumajitelem společnosti, která sponzorovala Baník Havířov. Nad rámec toho ještě uvedl, že přijal českou kulturu a je ateista.

Jiný žadatel, původem ze Sýrie, prac. č. 0538, naopak cítil potřebu se vymezit vůči svému původu. V rozkladu uvedl, že se distancuje od nezákonných aktivit př́íslušníků arabské komunity žijících v České republice. 13

Na závěr této palety argumentů uved'me ještě argument demografický, který přednesl žadatel původem z Ukrajiny, prac. č. 0450. Žadatel se snažil vyvážit své dlužné pojistné a penále na veřejném zdravotním pojištění, které aktuálně dosáhlo řádově stovek tisíc korun, poukazem na to, že je otcem dvou dětí s českým občanstvím. Hodnota lidského života má být dle názoru žadatele vyčíslena částkou přesahující 10 milionů Kč a jeho investice do české společnosti je tedy zatím cca 20 milionů.

Ačkoliv právě posledně zmíněná argumentace vyznívá na první pohled obzvláště alibisticky, otevírá možná nejzávažnější otázku naší společnosti - totiž že nesporným dlouhodobým přínosem naturalizace cizinců v České republice je vyrovnání stále většího demografického poklesu. Slovy prof. Možného: „Společnost, která nemá děti, nemá budoucnost. To se těžko vyvrací." "14

\section{REALITA}

Udělování státního občanství je výrazem státní suverenity. Kdo je však v praxi skutečně tím suverénem, který rozhodne, zda konkrétní osobě bude státní občanství České republiky uděleno, či nikoliv?

Je třeba přiznat, že v praxi tímto suverénem téměř nikdy není soud. Důvodů je hned několik. Prvním důvodem je relativně malé procento (v řádu jednotek procent) př́ípadů, kdy je ve věci rozhodnutí o zamítnutí žádosti o státní občanství České republiky ze strany žadatelů vůbec podána správní žaloba (k Městskému soudu v Praze) a ještě menší procento př́ipadů, kdy je následně podána kasační stížnost $\mathrm{k}$ Nejvyššímu správním soudu; o mizivé angažovanosti Ústavního soudu v této oblasti nemluvě. Dalším důvodem je dosud nejednoznačná judikatura soudů v otázce rozsahu soudního přezkumu správního

13 Tento případ otevírá ve vší nahotě ještě jiný problém - totiž předpoklad (existující však naštěstí jen v mysli některých žadatelů samotných), že by snad etnický původ žadatelů mohl snižovat jejich šanci na získání státního občanství České republiky. Budiž již na tomto místě předesláno, že provedený výzkum založený na analýze téměř 100 \% zamítavých rozhodnutí z let 2013-2016 žádnou podobnou tendenci nezaznamenal.

14 MOŽNÝ, I.: Obavy z migrace ano, strach ne. Evropa tančí, jak dovede. Reflex, 2016, č. 4, s. 25. 
uvážení. ${ }^{15}$ Až do roku 2005 přitom byl přístup k soudu v této otázce v důsledku tehdejší judikatorní praxe vyloučen úplně. ${ }^{16}$

V praxi je výkon státní moci v této oblasti realizován Ministerstvem vnitra a správní uvážení tohoto exekutivního orgánu je pro žadatele fakticky onou branou ke státnímu občanství České republiky. Jaká tedy tato praxe je?

Vcelku intuitivně bylo možno očekávat, že předpokladem pro získání státního občanství České republiky je pobyt na jejím území a dále též znalost jazyka - češtiny. V tomto ohledu výsledky výzkumu nikterak nepřekvapily a z hlediska základních hodnot jsou tyto dva požadavky relativně neutrální a nebude o nich na tomto místě blíže pojednáno.

Co se tedy ukázalo jako skutečně prubířský kámen v otázce naturalizace v České republice? Tímto prubířským kamenem je požadavek, aby u žadatelů nebyla dána některá ze zákonem stanovených negativních podmínek. A opravdu - podmínky pro naturalizaci jsou v České republice v praxi nastaveny především negativně, tj. jako možné překážky, nikoliv jako předpoklady.

Těchto negativních podmínek je v $\S 13$ odst. 2 a $\S 14$ ZSO nastavena celá řada, v praxi však hrají roli především tyto tři:

1) bezpečnostní hrozba (kód Z),

2) dluh na veřejném zdravotním pojištění (kód E2),

3) netransparentnost prŕijmů (kód N).

\section{BEZPEČNOSTNÍ HROZBA}

Dle $\S 13$ odst. 2 ZSO platí, že státní občanství České republiky nelze udělit žadateli, který ohrožuje bezpečnost státu, jeho svrchovanost a územní celistvost, demokratické základy, životy, zdraví, nebo majetkové hodnoty.

Bezpečnostní hrozba je nepochybně jedním z možných důvodů pro odepření naturalizace. Nebýt hrozbou je možná tou prvotní, vcelku intuitivní podmínkou naturalizace. Tato podmínka je imanentní již samotnému obsahu pojmu státní občanství, jakožto „pouta, založeného na existenci vzájemných práv a povinností“. 17

Skutečným ústavněprávním problémem této podmínky není její zakotvení, nýbrž fakt, že zamítavé rozhodnutí o žádosti o udělení státního občanství České republiky opřené o skutečnost, že žadatel představuje ohrožení bezpečnosti státu, je dle $§ 26$ ZSO

15 V této otázce dodnes přetrvává rozdílnost v názorech mezi jednotlivými senáty Městského soudu v Praze. K vývoji judikatury do roku 2009 srov. POTMĚŠIL, J.: Judikatura (převážně NSS) a dalši prameny k otázkám (ne) uděleni státního občanstvi ČR, se zvláštním zřetelem ke správnímu uvážení. http://prestupky .blogspot.cz/search?q=judikatura+ke+st $\% \mathrm{C} 3 \% \mathrm{~A} 1 \mathrm{tn} \% \mathrm{C} 3 \% \mathrm{ADmu}+\mathrm{ob} \% \mathrm{C} 4 \% 8 \mathrm{Danstv} \% \mathrm{C} 3 \% \mathrm{AD}$

16 Blíže viz MOLEK, P. - ŠIMÍČEK, V.: Udělování státního občanství - na cestě od milosti státu k soudně přezkoumatelnému správnímu uvážení. Právník, 2005, č. 2, s. 137 an. ŠIMÍČEK, V.: Verwaltungsgerichtsbarkeit in der Tschechischen Republik - Ausgewählte Probleme. Jahrbuch für Ostrecht, 2009, č. 2, s. 362 an.

17 Rozsudek Mezinárodního soudního dvora ve věci Nottebohm z 6. 4. 1955. 
vyloučeno ze soudního přezkumu. Toto ustanovení bylo již terčem odborné kritiky ${ }^{18}$ a je v současné době napadeno u Ústavního soudu.

Dalším problémem v těchto př́ípadech je otázka, kdo je tu skutečným suverénem rozhodujícím o zamítnutí žádosti. Ministerstvo vnitra tak totiž činí na základě informací získaných podle $\S 22$ odst. 3 ZSO od zpravodajských služeb a ani v průběhu tohoto výzkumu nebyla nijak rozptýlena hypotéza, že správní úvaha Ministerstva vnitra je tu prakticky nulová a jsou pouze převzaty závěry zpravodajských služeb.

Podíl těchto př́ípadů (kód Z) na celkovém počtu zamítnutých žádostí byl ve zkoumaném období u rozhodnutí vydaných podle ZSO cca $13 \%{ }^{19}$

\section{DLUH NA VEŘEJNÉM ZDRAVOTNÍM POJIŠTĚNÍ}

Jedním z nejpřekvapivějších zjištění tohoto výzkumu je skutečnost, že zdaleka největši počet žádostí o státní občanství České republiky bylo zamítáno z důvodu, že žadatel měl v minulosti dluh na veřejném zdravotním pojištění. Podíl těchto případů (kód E2) na celkovém počtu zamítnutých žádostí ve zkoumaném období vydaných podle ZNPSO činil cca $56 \%$ a podle ZSO $16 \%{ }^{20}$ Zdůrazněme na tomto místě, že se ve většině př́ípadů jednalo o dluh již uhrazený. ${ }^{21}$

Zákonnou oporu pro tento postup lze nalézt v požadavku, aby žadatel plnil, mimo jiné, i své povinnosti na úseku veřejného zdravotního pojištění. ${ }^{22}$ Ministerstvo vnitra pak v celé řadě případů tento zákonný požadavek rozpracovává, když v odůvodnění zamítavých rozhodnutí poukazuje na to, že ,veřejné zdravotní pojištění je solidárním systémem a řádné fungováni tohoto systému, a tím i následné fungováni zdravotni péče, je pak podstatným zpưsobem ovlivněno i jeho řádným průběžným financováním “.23 Tuto úvahu pak ve stovkách svých rozhodnutí opírá o rozsudek Nejvyššího správního soudu ze dne 13. 3. 2008, č.j. 5 As 51/2007-105, podle kterého: „, Smyslem a účelem uvedené podminky je vyloučit riziko, že uchazeč o uděleni českého státního občanství bude porušovat právní předpisy i jako státni občan České republiky, přičemž jednání každého, kdo se ucházi o udèleni státniho občanství České republiky, by mělo být transparentní a prosté všech pochybností. "Paradoxní je, že v citovaném případě řešeném Nejvyšším správním soudem tento soud naopak dal stěžovateli za pravdu, když zdůraznil princip proporcionality při posuzování zmíněné podmínky.

18 KINDLOVÁ, M. Ústavnost soudní výluky u neudělení státního občanství z důvodu ohrožení bezpečnosti státu? Správní právo, 2015, č. 7-8, s. 404-419.

19 V absolutních číslech šlo o 64 případů z 500. V překvapivě velkém počtu z těchto případů (v 17) bylo posléze žádosti vyhověno v rozkladovém řízení, a to s odůvodněním, že ministr vnitra si vyžádal aktualizované informace od zpravodajských služeb a zjistil, že bezpečnostní riziko u žadatele již není dáno.

$20 \mathrm{~V}$ absolutních číslech šlo o 347 př́ípadů z 623 podle ZNPSO a o 80 př́ípadů z 500 podle ZSO.

21 Byt' většinou byl tento dluh uhrazen až v souvislosti s podáním žádosti o státní občanství České republiky. Celkový podíl případů, ve kterých dluh přetrvával i v okamžik vydání prvoinstančního rozhodnutí Ministerstva vnitra, činil jen $6 \%$ ze všech př́padů zamítnutých z tohoto důvodu.

$22 \S 7$ odst. 1 písm. e) ZNPSO, resp. § 14 odst. 6 ZSO.

23 Viz např. prac. č. 0359. 
Plnění povinností na úseku veřejného zdravotního pojištění je $\mathrm{v}$ praxi natolik vysokou hodnotou, že ani jinak vysoká rodinná integrace nebo několik desítek let trvající pobyt na území České republiky nejsou shledány jako důvody pro její prominutí.

Např. v případě prac. č. 0663 byl žadatel tlumočníkem, žil v České republice již od roku 1983 a jeho děti již českými státními občany jsou. Ministerstvo vnitra však délku pobytu často používá naopak jako argument proti stěžovateli, když uvádí, že ,, tato dlouhá doba pobytu v České republice dala žadateli nepochybně víc než přiměrenou př́ležitost adekvátně se seznámit s rozsahem a obsahem jeho práv a povinností vičci České republice a tato práva a povinnosti také beze zbytku naplňovat "(cit. dle prac. č. 0212).

Argumentem, který by převážil nesplnění této podmínky, nemusí být ani vzdělání. V př́ípadě prac. č. 0420 Ministerstvo vnitra uvedlo, že , u žadatelky, vysokoškolsky vzdělané osoby, usilujicí o prijietí do cizího státního svazku, lze oprávněně očekávat, že se rádnè seznámí s právním řádem České republiky“.

Za důvod hodný zvláštního zřetele pro prominutí této podmínky nelze dle názoru ministra vnitra uvedeném $\mathrm{v}$ prac. č. $0593 \mathrm{r}$ považovat ani skutečnost, že dceři žadatele bylo již státní občanství České republiky uděleno, ani fakt, že k poslednímu pochybení na úseku veřejného zdravotního pojištění a důchodového pojištění došlo v roce 2008, ani fakt, že se zde zdržuje již skoro 20 let.

Posledně uvedený př́ípad byl nicméně rozhodován podle minulé právní úpravy (ZNPSO). Podle té současné (ZSO) je posuzováno plnění povinností na úseku veřejného zdravotního pojištění jen za poslední tři roky před podáním žádosti. Navíc lze v praxi Ministerstva vnitra vypozorovat větši benevolenci než dř́ve, pokud jde o výši dluhu, když k menším dlužným částkám nepřihlíží. $Z$ rozhodnutí prac. č. 0823 lze vytušit, že hranice tolerance se tu pohybuje kolem 5000,- Kč.

\section{NETRANSPARENTNOST PŘÍJMU゚}

V novější praxi vystupuje stále více do popředí požadavek, aby žadatel o státní občanství prokázal zdroje svých příjmů. Tento požadavek je podle současné úpravy již výslovně zakotven $\mathrm{v} \S 14$ odst. $7 \mathrm{ZSO}$ a jeho splnění dokonce ani není možné prominout podle $\S 15 \mathrm{ZSO}$.

Podíl těchto př́padů (kód N) na celkovém počtu zamítnutých žádostí ve zkoumaném období vydaných podle ZSO je cca $10 \%,{ }^{24}$ nicméně již za účinnosti ZNPSO bylo vydáváno taktéž cca $10 \%{ }^{25}$ rozhodnutí opřených o tento, byt' v zákoně tehdy výslovně neupravený důvod (kód $\mathrm{n}$ ).

Pochybnosti o transparentnosti př́ijmů žadatelů jsou v mnoha případech zjevné. Např. v př́ípadě prac. č. 0783 žadatelka uvedla svůj měsíční prŕíjem ve výši 3200 až 5000 Kč. Vzhledem k výši měsíčního nájmu na byt, který činí 9000,- Kč měsíčně, je zjevné, že žadatelkou doložená výše př́ijmů nemohla pokrýt její životní náklady, když jejím jediným zdrojem příjmů byl příspěvek na živobytí, příspěvek na bydlení a pod-

$24 \mathrm{~V}$ absolutních číslech šlo o 49 případů z 500 podle ZSO.

$25 \mathrm{~V}$ absolutních číslech šlo o 62 príípadů z 623 podle ZNPSO. 
pora $\mathrm{v}$ nezaměstnanosti. $\mathrm{V}$ př́padě prac. č. 0785 činil hrubý měsíční př́ijem žadatelky 15 tis. Kč. Manžel žadatelky se dle doložených daňových přiznání pohyboval vždy ve ztrátě. Otevřenou otázkou tak dle názoru Ministerstva vnitra zůstalo, z jakých finančních zdrojů uhrazuje žadatelka náklady svého života, z jakých zdrojů žije celá rodina (manžel a dítě), z jakých prostředků hradí splátky poskytnutého hypotečního úvěru, popř. z jakých zdrojů financovala svá vysokoškolská studia na soukromé škole. V př́ipadě prac. č. 0849 žadatel odkázal na své úspory a na úspory svých rodičůu, které jsou mu údajně zasílány z Vietnamu. Tato tvrzení však ničím nepodložil - nedoložil např. splnění oznamovací povinnosti při přeshraničním převozu nebo bezhotovostní převod finančních prostředků z ciziny.

\section{ZÁVĚR}

Z provedeného výzkumu vyplývá, že základní hodnotou, která je $\mathbf{v}$ procesu naturalizace v České republice zkoumána, je absence zákonem předvídaných překážek pro jeho udělení. Touto překážkou je $\mathrm{v}$ praxi z velké části neplacení pojistného na veřejném zdravotním pojišstění. Toto zjištění je přinejmenším překvapivé a jen těžko bychom mohli tvrdit, že odpovídá obecně očekávané představě o hodnotách České republiky. Na druhou stranu lze př́stup Ministerstva vnitra v této oblasti chápat - je totiž jen vykonavatelem vůle zákonodárce, který podmínky pro udělení státního občanství v zákoně výslovně stanovil. Jakékoliv zohledňování ,hodnot“ by totiž mohlo vést $\mathrm{k}$ libovůli při výkladu, co se těmito hodnotami vlastně myslí. Současná právní úprava nicméně prostor pro takový výklad otevírá - je jím především dřive neupravený požadavek na ,integraci“ dle $\S 13$ odst. $1 \mathrm{ZSO}$, a to vedle integrace rodinné a pracovní i integraci sociální. Právě aplikace této sociální integrace (kód S) se jeví být do budoucna prostorem pro větší promítnutí základních hodnot České republiky do procesu naturalizace. Je to však i prostor, který by neměl zůstat př́liš široký a který by měl být zároveň pod veřejnou kontrolou, a to i prostřednictvím moci soudní.

Mgr. Pavel Kandalec, Ph.D., LL.M.

Právnická fakulta Masarykovy univerzity

pavel.kandalec@law.muni.cz 